\title{
Tourism attraction and CBT of agro tourism in Cafe Sawah Pujon Kidul
}

\author{
Fifi Nofiyanti, ${ }^{1, *}$, R.M.W. Agie Pradhipta ${ }^{1}$, Devita Gantina ${ }^{1}$, Rianto ${ }^{1}$, and Wayu Eko \\ Yudiatmaja $^{2}$ \\ ${ }^{1}$ Sekolah Tinggi Pariwisata Trisakti, Jakarta, Indonesia \\ ${ }^{2}$ Department of Public Administration, Universitas Maritim Raja Ali Haji, Tanjungpinang, Indonesia
}

\begin{abstract}
This study aims to reveal the tourist attractiveness and application of community based tourism (CBT) in the agro-tourism of Café Sawah Pujon. The research method used is qualitative with ethnographic techniques. Researchers experienced and interacted directly at Café Sawah Pujon Kidul. The results showed that the tourist attraction presented by Café Sawah Pujon Kidul Malang is a natural tourism that uses agricultural land as a tourist attraction. This tourist attraction uses a CBT application model in developing agro-tourism. The village community plays an important role in the management and development of this agro-tourism. The manager welcomes tourists friendly, the use of uniforms, the use of digital ticket confirmation, and the role of tourists in managing the agrotourism offered. The accessibility of this agro-tourism is easy to pass, has good roads, and clear directions, the manager of the tourist attraction is also on guard to take tourists to tourist sites. The CBT concept that is applied to tourism development is managed entirely by utilizing the community in the Pujon Kidul rice fields. People can also do entrepreneurship by selling souvenirs, such as souvenirs, clothing, plantation products (chilies, mustard greens, broccoli, and other vegetables), as well as parking management.
\end{abstract}

\section{Introduction}

\subsection{Background}

The attraction of agro-tourism is an attractive thing for tourists today. Rachmawati [1] Member of Commission X DPR RI, Ratih Megasari Singkarru said the concept of agro became a tourism concept that would be in great demand in Indonesia.

Utilization of plantations and village agriculture is developed into a tourist attraction that attracts tourists. Tourist attractions make tourists curious and want to travel to tourist

* Corresponding author: fifinofi17@gmail.com 
destinations that are hits and new tours. Now the village has become a tourist destination. However, not all tourist villages or tours in the village empower and improve the economy and welfare of the local community in the village.

Yudiatmaja, et.al [2], The diversity of studies has explained the effect of social policy on the community. Unfortunately, we still lack understanding of the case in the context of rural coastal communities because most of the study is conducted in rural agricultural communities.

The existing trend is about rural tourism or known as tourist village. The formation of a tourism awareness group in the village, to the development of a tourist village to create tourist destinations and manage tourism.

The existence of electricity constraints that are not owned by the village is an obstacle to the development of tourist villages. There needs to be an effort by the government and village managers to overcome these problems. So that the solution is an effort to develop a village into a tourist village or tourism in the village.

Based on the results of Hermawan's research [3], that the development of tourist villages has a positive impact on the economic development of local communities in Nglanggeran Village, including: increasing community income; increase employment and business opportunities; increasing local community ownership and control; increase government revenue through tourist levies.

Observing several villages that became tourist villages, they were divided into 2 , namely tourism for village community development and tourism with village community workers. Indonesia has beautiful and diverse natural resources, so many can be used as tourist destinations. Before the Covid-19 pandemic, tourism was increasing in demand by the public. Village communities gain experience by managing their villages into tourist destinations, and have jobs from these activities. However, there are also tourist destinations that are managed and developed by the private sector. Based on some news and social media information, the Pujon Kidul Rice Field Cafe tourist destination is currently viral and has been developed since 2017 until now.

Syaribulan and Nawir [4] Agrotourism or agrotourism is defined as a form of tourism activities that utilize agro-business (agribusiness) as a tourist attraction. This tourist destination is to increase knowledge, experience, recreation and business relations in agriculture.

Naimah, et.al [5] One of the tours that contribute to developing tourism in Indonesia is one of them in Malang Regency. This tourism is able to help the community in improving the economy and community empowerment.

Community based tourism (CBT) is an effort for sustainable development of tourism based on local communities by paying attention to the cultural, social, and sustainability of rural communities in utilizing tourism.

The attractiveness of agro-tourism is an interesting thing for tourists today. The use of plantations and village agriculture is developed into a tourist attraction that attracts tourists.

The success of Pujon rice fields in developing agro-tourism in the village has become an attraction for tourists visiting Malang and its surroundings

This study aims to reveal the tourist attractiveness and application of community based tourism (CBT) in the agro-tourism of Café Sawah Pujon."

Utilizing village natural resources in Pujon Kidul Village by looking at the efforts to implement community based tourism. Therefore, it is necessary to know what kind of tourist attraction Pujon Kidul Village has through the Pujon Kidul Sawah Cafe.

It becomes an interesting thing in tourism when the village is used as a tourist destination, starting from the attraction, management, and condition of the community around tourist destinations in the village. So that in the development of tourist destinations in other villages, we can learn from villages that have succeeded in building tourist 
destinations by working together and advancing the local village community. Because as a community, they are beneficiaries who live in a village.

\subsection{Literature Review}

Simanihuruk [6], tourism products are places that have Attraction as a supporting factor as Attracting tourists to visit the tour and have Adequate facilities such as access to travel, Recreation and many things that make Tourists interested in coming to the place.

According to Cooper et al [7], tourism attraction must have four components namely; Attractions, Accessibility, Amenities, and Anillary services tourism support services.

Amerta [8], the development of community based tourism is expected to provide some benefits for society, particularly the economic benefit. So, the environmental preservation can be implemented by the local communities, their Population distribution, and creating alternative tourism

Sunaryo in Rizkianto and Topowijono [9] community based tourism, namely: a. Involve the community in decision making. B. There is certainty that the local community will receive the benefits $\mathrm{c}$. providing education about tourism to the community.

Dewi, et al. [10], the tourism authority in many countries introduces the implementation of CBT for sustainable tourism initiative. Therefore, the benefits of tourism industry can be fruitful for the social, environmental and local communities. This concept also is adopted in Indonesia.

As Choi and Sirakya from Lee [11] indicated, establishing efficient government policies can be beneficial for sustainable community-based tourism. Moreover, resorts are affected by technological advances that can contribute to the monitoring/management of tourism impacts.

It can be concluded that community-based tourism can be utilized by local communities in villages and the rural economy can be developed for sustainable tourism development. Agrotourism plays a very important role in supporting the economy, creativity, and increasing the presence of tourism in the village.

Sartika \& Wargadinata [12], CBT is tourism which residents manage their resources in the community as the tourism supply and provide it to tourist.

Nurhidayati [13] CBT, namely: 1) a form of tourism that provides opportunities for local communities to control and be involved in tourism management and development, 2) people who are not directly involved in tourism businesses also benefit, 3) demand political empowerment and democratization and distribution of benefits to disadvantaged communities in rural areas.

\section{Research methods}

The research method used is qualitative with ethnographic techniques. Researchers experienced and interacted directly at Café Sawah Pujon Kidul.

Ethnographic research methods. Conducting research with realist ethnography, revealing existing facts based on observations, surveys, and interviews with managers of tourist destinations at Cafe Sawah Pujon Kidul, people who care about tourism, and traders.

Friberg [14], tensionless ethnography is described as a method in which the conceptual objects and attitude are conceived as similar among the ethnographer and the Others. As the academic world of ethnography becomes an assimilated part of the world of policy and industry, it could be argued that we are about to lose a self-reflexive qualitative approach.

Emzir ([15]are as follows: 1) Ethnography assumes research interests whose main principles are influenced by the cultural understanding of society. 2) Ethnographic research assumes an ability to identify communities that are relevant to their interests. 3) With 
ethnographic research, researchers are assumed to be able to understand the cultural advantages of the society being studied, master the language or technical jargon of the culture and have findings based on comprehensive knowledge of the culture.

Research focus is Agro Tourism in Cafe Sawah Pujon Kidul, Malang. This research time December 2020. The research subjects are tourist destination managers, traders, people who work in tourist destinations. Researchers experienced firsthand and felt at the tourist destination of Cafe Sawah Pujon Kidul.

\section{Results and discussion}

The results of research conducted at the tourist destination Café Sawah Pujon Kidul which is located in Malang. This tour is close to Jatim Park, Transport Museum, and several other tourist destinations. Tourist destinations that are becoming known through social media uploads on Instagram, Facebook, and YouTube. Café Sawah Pujon Kidul has a unique and distinctive tourist attraction and is able to bring in visitors.

Based on tourist attraction, which is divided into 4 indicators, namely: attractions, accessibility, amenities, and anillary service tourism. The following are the results of research on tourist attractions.

\subsection{Tourism Attraction}

\subsubsection{Attractions}

The destination of Café Sawah Pujon Kidul is a natural destination. The tourist attraction offered is the view of the rice fields and several other tourist attractions. The topography of Pujon Kidul village is above the hills with an altitude of $1200 \mathrm{~m}$ above sea level. The Pujon Kidul rice field café started with the idea of the community establishing a simple café in 2011. In 2017 Pujon Kidul Sawah Café was inaugurated by the Malang Regent. This tourist destination elevates agro-tourism. Rice fields are used as a tourist attraction.

The discussion about tourist attraction is discussed by Hermawan [16] Pujon Kidul village has really become a tourist village with a lot of variety. Attractions that can be visited. Second, to maintain the competitive advantage of the area beautiful rice fields, the village of Pujon Kidul and its surroundings should submit proposals and regulation to a higher government in order to make Pujon Kidul village a village conservation to maintain the beauty and preservation of nature is maintained and does not change

The tourist attraction of Café Sawah Pujon is the view of the rice fields, picking strawberries, picking apples, water tours, swimming pools, boats, photo spots, children's games and a café in the middle of the rice fields. The tourist attraction as in pictures 1,2, 3, Café Sawah Pujon has a vast, beautiful, and cool nature. The price of admission tickets in December 2020 is IDR 10,000. Tickets can be exchanged for culinary delights, such as fried cassava, boiled peanuts, and entrance tickets to other rides. However, there are some rides that you have to buy a ticket for. The ticket price for Cafe Sawah Pujon Kidul is cheap.

Strawberry picking activities also saw firsthand the planting process, to its care. Visitors can eat strawberries directly in the garden and can take them home, but the weight of the fruit is calculated and pays an additional fee. Strawberry picking tours and Café Sawah Pujon Kidul are not limited in time. 


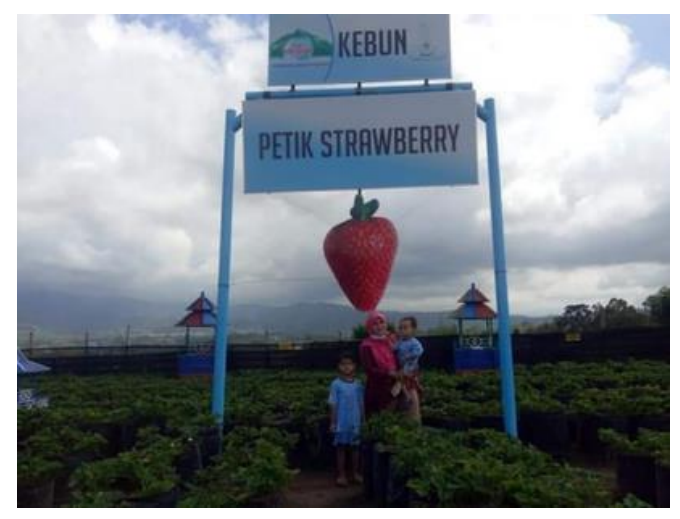

Fig. 1. Strawberry picking activities.

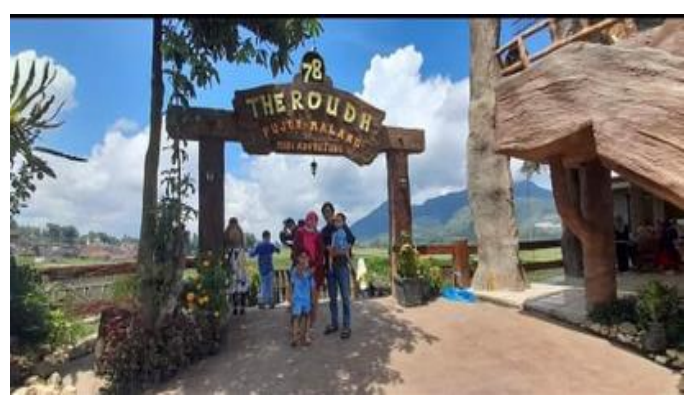

Fig. 2. The roudh 78 .

Tourist attractions at The Roudh 78 include hand boats, water rollers, water balls, goose boats, rowing boats, horse riding, paint balls, feeding fish, educating rabbits, horses and goats. The Roudh comes from the word raudah which means garden. This location is often called family tourism. Here tourists can also enjoy delicious culinary.

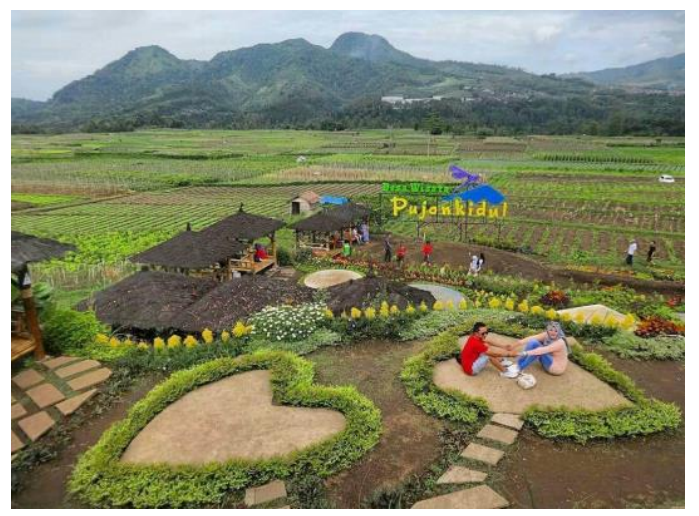

Fig. 3. Cafe rice field view.

The Sawah Pujon Cafe Destination provides the feel of eating in the fields, views of the rice fields, and several instagramable photo spots. Being in this tourist destination for a long time, will not be felt. Due to the wide range of tourist sites and various tourist attractions. Visitors can also enjoy regional food, shopping for vegetables and fruit. 
Children can be happy and satisfied playing at the tourist destination of Cafe Sawah Pujon Kidul.

\subsubsection{Accessibility}

Accessibility from the destination Café Sawah Pujon Kidul has an easy road to pass, there are road signs to tourist sites. Every tourist attraction offered there is a manager, namely the local community.

The access road to the Pujon Kidul rice field cafe destination is easy to pass, the road is good, there are road signs leading to the tour, welcomed by the youth of the tour manager.

\subsubsection{Amenities}

The facilities owned by this destination are gazebos, pavilions, culinary centers, playgrounds, water games, fruit gardens, prayer rooms, toilets, parking, photo spots, and shopping tours. The price offered in the sale is also relatively affordable.

\subsubsection{Anillary services tourism}

Cafe Sawah Pujon destinations are managed from digital entry tickets, ticket checkers, voucher exchangers, traders, strawberry garden owners, cleaners, vegetable sellers, fruit sellers, and parking managers. All empower the people of Pujon Kidul Village.

Malang Regency strongly supports the efforts of the Pujon Kidul Village community in building and developing the Pujon Kidul rice field café destination. It can be seen from the community's efforts from 2017 to 2021 to get better and provide welfare for the village community. The development of Pujon Kidul rice field cafe tourism is also supported by Bank BNI which provides small and medium business loans (KUR).

The tourism awareness group that manages the Pujon Kidul rice field café also provides support, manages it well, and invites the surrounding community to contribute to the tourism.

\subsection{Community Based Tourism (CBT)}

The results showed that the tourist attraction presented by café sawah pujon kidul malang is a natural tourism that uses agricultural land as a tourist attraction. This tourist attraction uses a cbt application model in developing agro-tourism.

The village community plays an important role in the management and development of this agro-tourism. The manager welcomes tourists friendly, the use of uniforms, the use of digital ticket confirmation, and the role of tourists in managing the agro-tourism offered.

The tourist attraction in the form of attractions at the pujon rice field cafe, tourists can pick plantation products, witness firsthand the process of caring for plantation products such as strawberries. The facilities provided by the pujon rice field cafe are a cafe dining atmosphere between rice fields and garden views.

There are other tourist attractions, such as water games, swimming pools, children's games, and culinary delights. Tourists can exchange tickets for stewed foods such as cassava, peanuts, sweet potatoes.

Tickets can also be used to enter other tourist areas in the pujon kidul rice field café environment. The accessibility of this agro-tourism is easy to pass, has good roads, and clear directions, the manager of the tourist attraction is also on guard to take tourists to tourist sites. The CBT concept that is applied to tourism Development is managed entirely 
by Utilizing the community in the pujon kidul Rice fields. People can also do Entrepreneurship by selling souvenirs, Such as souvenirs, clothing, plantation, Products (chilies, mustard greens, Broccoli, and other vegetables), as well as Parking management.

The application of CBT is in line with the research of Agfianto, et.al [17] on Cafe Sawah Pujon Kodul management is left to Pokdarwis and the community only given business space for the establishment of kiosks around tourist destinations if you want get a share of the tourism cake. Cafe Sawah Pujon Tourism is managed and developed by the local community.

\section{Conclusion}

The conclusion of this research is that the tourist attraction presented by Café Sawah Pujon Kidul Malang is a natural tourism that uses agricultural land as a tourist attraction. This tourism object uses the CBT application model in developing agro-tourism. Village communities play an important role in the management and development of this agrotourism. The manager welcomes tourists in a friendly manner, the use of uniforms, the use of digital ticket confirmations, and the role of tourists in managing the offered agrotourism. The facilities provided by the Pujon rice field cafe are a cafe dining atmosphere between rice fields and garden views. There are other tourist attractions, such as water games, swimming pools, children's games, and culinary delights. Tourists can exchange tickets for boiled foods such as cassava, peanuts, sweet potatoes. The ticket can also be used to enter other tourist areas in the Pujon Kidul rice field cafe environment.

The accessibility of this agro-tourism is easy to pass, has good roads, and clear directions, the manager of the attraction is also on guard to take tourists to tourist sites. The CBT concept applied to tourism development is fully managed by utilizing the community in the Pujon Kidul rice fields. People can also become entrepreneurs by selling souvenirs, such as souvenirs, clothing, plantation products (chili, mustard greens, broccoli, and other vegetables), as well as parking management.

Community empowerment-based tourism development is very beneficial for local communities. The community is invited to build their village and be introduced to tourism development. All empower the people of Pujon Kidul Village.

\section{References}

1. D. L. Rachmawati, Agrowisata Akan Jadi Konsep Wisata yang Banyak Diminati, (2021). 2. W. E. Yudiatmaja, D. Kristanti, I. Y. Prastya, Y. Yudithia, T. Samnuzulsari, S. Suyito, and D. P. Safitri, in E3S Web Conf. (2021).

3. H. Hermawan, J. Pariwisata III, (2017).

4. Syaribulan. K. and Muhammad. N., J. Equilib. Pendidik. Sosiol. III, (2016).

5. H. Naimah, R. Arifin, and S. Asiyah, J. Ilm. Ris. Manaj. 09, 78 (2020).

6. M. Simanihuruk, E-Journal Tour. 6, 210 (2019).

7. F. Cooper, G. D, and W. S., Tourism, Principles and Prantice (Logman, London, 1995).

8. I. M. S. Amerta, Int. J. Soc. Sci. Humanit. 1, 97 (2017).

9. N. Rizkianto and Topowijono, J. Adm. Bisnis 58, 20 (2018).

10. N. I. K. Dewi, I. P. Astawa, I. W. Siwantara, and I. G. A. B. Mataram, in 2nd Int. Jt. Conf. Sci. Technol. (2017).

11. T. H. Lee, F. H. Jan, and J. T. Liu, Developing an Indicator Framework for Assessing Sustainable Tourism: Evidence from a Taiwan Ecological Resort (Published by Elsevier 
Ltd, 2021).

12. I. Sartika and E. Wargadinata, in Proceeding ICOGISS (2019), pp. 293-301.

13. Nurhidayati. S.E., J. Masyarakat, Kebud. Dan Polit. 20, (2007).

14. T. Friberg, Ethnography 22, 207 (2019).

15. Emzir, Metodolohi Penelitian Kualitatif: Analisis Data (PT Raja Grafindo Persada Pusat, Jakarta, 2011).

16. H. Hermawan, Desa Pujon Berbenah Jadi Desa Wisata Terbaik di Malang (2017).

17. T. Agfianto, M. Antara, and I. W. Suardana, J. Master Pariwisata 05, 259 (2019). 